J. D. Jenkins

E. J. Allen

E. D. Blakeman

Material Control and Accountability Procedures for a Waste Isolation Repository 


\section{DISCLAIMER}

This report was prepared as an account of work sponsored by an agency of the United States Government. Neither the United States Government nor any agency Thereof, nor any of their employees, makes any warranty, express or implied, or assumes any legal liability or responsibility for the accuracy, completeness, or usefulness of any information, apparatus, product, or process disclosed, or represents that its use would not infringe privately owned rights. Reference herein to any specific commercial product, process, or service by trade name, trademark, manufacturer, or otherwise does not necessarily constitute or imply its endorsement, recommendation, or favoring by the United States Government or any agency thereof. The views and opinions of authors expressed herein do not necessarily state or reflect those of the United States Government or any agency thereof. 


\section{DISCLAIMER}

Portions of this document may be illegible in electronic image products. Images are produced from the best available original document. 
Printed in the United States of America. Available from National Technical Information Service

U.S. Department of Commerce

5285 Port Royal Road, Springfield, Virginia 22161

Price: Printed Copy $\$ 4.50$; Microfiche $\$ 3.00$

This report was prepared as an account of work sponsored by an agency of the United States Government. Neither the United States Government nor any agency thereof, nor any of their employees, contractors, subcontractors, or their employees, makes any warranty, express or implied, nor assumes any legal liability or responsibility for any third party's use or the results of such use of any information, apparatus, product or process disclosed in this report, nor represents that its use by such third party would not infringe privately owned rights. 
ORNL/TM-6162

Dist. Category UC-70

Contract No. W-7405-eng-26

Engineering Technology Division

MATERIAL CONTROL AND ACCOUNTABILITY PROCEDURES FOR A WASTE ISOLATION REPOSITORY

J. D. Jenkins

E. J. Allen

E. D. Blakeman

Date Published - May, 1.978

NOTICE

This report was prepared as an account nf wark sponsored by the United States Government. Neither the United States nor the United States Department of Energy, nor any of their employees, nor any of their cuntractors, subeontractors, or their employees, makes any warranty, express or implied, or assumes any legal

liability or responsibility for the accuracy, completeness

or lisefulness of any information, apparatus, pouduct an

process disclosed, or represents that its use would not

infringe privately owned rights.

Prepared by

OAK RIDGE NATIONAL LABORATORY

Oak Ridge, Tennessee 37830

operated by

UNION CARBIDE CORPORATION

for the

DEPARTMENT OF ENERGY 
THIS PAGE

WAS INTENTIONALLY

LEFT BLANK 
CONTENTS

$\underline{\text { Page }}$

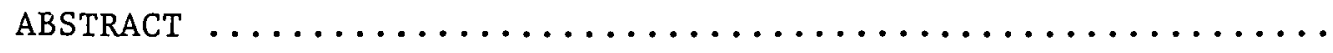

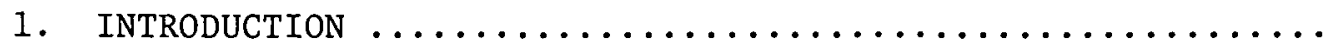

2. WASTE CHARACTERISTICS AFFECTING ACCOUNTABILITY .........

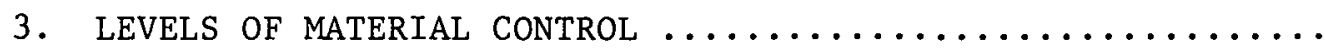

4. EVALUATION OF MATERIAL CONTROL AND ACCOUNTABILI'YY NEEDS ...

5. TECHNICAL OPTIONS FOR ITEM CONTROL $\ldots \ldots \ldots \ldots \ldots \ldots \ldots$

6. TECHNICAL OPTIONS FOR TAMPER INDICATION ............. 15

7. TECHNICAL OPTIONS FOR SNM ASSAY $\ldots \ldots \ldots \ldots \ldots \ldots \ldots \ldots \ldots$

8. CONCLUSIONS AND RECOMMENDATIONS $\ldots \ldots \ldots \ldots \ldots \ldots \ldots \ldots \ldots$

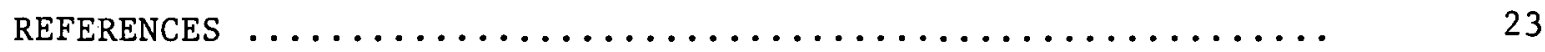

Appendix A. SNM ACCOUNTABILITY FOR ALTERNATE WASTE TYPES .... 25 


\title{
MATERIAL CONTROL AND ACCOUNTABILITY PROCEDURES FOR A WASTE ISOLATION REPOSITORY
}

\author{
J. D. Jenkins \\ E. J. Allen E. D. Blakeman
}

\begin{abstract}
The material control and accountability needs of a waste isolation repository are examined. Three levels of control are discussed: (1) item identification and control, (2) tamper indication, and (3) quantitative materlal assay. A summary of waste characteristics is presented and, based on these, plus a consideration of the accessibility of the various types of waste, material control by item identification and accountability (where the individual waste container is the basic unit) is recommended. Tamper indicating procedures are also recommended for the intermediate and low level waste categories.
\end{abstract}

\section{INTRODUCTION}

This report addresses the special nuclear material* (SNM) control and accountability needs and requirements of a nuclear waste terminal storage facility. In a companion document ${ }^{1}$ we have reviewed the status and capabilities of nondestructive assay technology, and assessed the potential for application of those techniques to the material accountability and control problems peculiar to a nuclear waste storage facility. The conclusions reached in that work, reproduced in summary form here in Sect. 7 , indicate substantial limitations in the applicability of nondestructive methods to nuclear waste assay at a storage facility. Thus, we here address alternative methods of material control which are available for safeguards and accountability purposes, and present our opinions of what will constitute an acceptable system.

*Special nuclear material is defined in 10CFR 70.4 paragraph (m) to mean (1) plutonium, uranium-233, uranium enriched in the isotope 233 or in the isotope 235, and any other material which the commission, pursuant to the provisions of Section 51 of the Atomic Energy Act of 1954, determines to be special nuclear material; or (2) any material artificially enriched by the foregoing but does not include source material. 
This study was performed for the Office of Waste Isolation (OWI) which is responsible for the National Waste Terminal Storage (NWTS) program. The opinions and recommendations expressed in this report are, however, the authors', and in no way represent OWI policy.

A waste terminal storage facility will require safeguards similar to that of any nuclear facility. ${ }^{2}$ The purpose of the system will be to protect the health and welfare of the public by preventing the theft, diversion or loss of nuclear material and thus its subsequent use by unauthurized personnel for any purpose.

The level of protection demanded of the safeguards system will depend to a large extent on material characteristics. If nuclear material Is 1 in an undesirable form, or is not a significant threat material, the safeguards measures need not be as stringent as for more attractive or hazardous nuclear material.

Some guidelines on safeguards requirements are available in the Code of Federal Regulations ${ }^{2}$ and in a number of the Nuclear Regulatory Commission's Regulatory Guides. ${ }^{3-10}$ However, many of the problems peculiar to a waste repository have not yet been explicitly addressed. It is clear, however, that the safeguards system must consist of a physical security component and a material control and accountability component. The physical security system functions to prevent the unauthorized movement of nuclear materials and persons into and out of the facility. The material control and accountability system provides means for detecting and quantifying possible losses of materials.

The report consists of seven sections. The next presents in summary form, a description of the chemical and radinlogical characterietice of the four anticipated types of waste materials, the container geometries, and the anticipated throughputs. These factors all influence both the requirements for material control and the ability to implement various accountability techniques. The third section describes three general. levels of material control, the lowest of which requires only a system to count and verify receipt of waste containers; while the highest implies installation of a system where the contents of each container is quantitatively determined. In the fourth section we examine those characteristics of each waste type which determine the level of accountability 
required, and recommend a generic accountability level for each type. Following sections discuss the technical options available to implement the recommended level of control, and the final section presents a summary and our recommendations.

\section{WASTE CHARACTERISTICS AFFECTING ACCOUNTABILITY}

Material characteristics including chemical form, SNM concentration, radiation levels, and container size all influence both the need for a certain level of material accountability and the ability of given techniques to meet these needs.

It was assumed for this evaluation that the nuclear waste accepted at the reference design waste repositoryll will consist of four basic types: high level waste (HLW), cladding waste (CW), intermediate level waste (ILW), and low level waste (LLW). Descriptions of each of these waste types are presented in Table 1 , and physical and chemical characteristics of each waste type are presented in Table 2. Table 3 lists the approximate isotopic distribution of actinides expected in spent fuel and high level waste. The actinide isotopics in cladding wastes will be similar to that of spent fuel. Intermediate level wastes will contain actinides in variable isotopic concentrations intermediate between the two listed tabulations. Table 4 gives estimates of the neutrôn production rates per cubic meter from each type of waste. These values are only approximate since the composition of the waste types are variable, especially ILW and LLW, and hence the $(\alpha, n)$ contributions are difficult to estimate. Figure 1 illustrates the range of densities and radiation levels anticipated from each of the four waste categories. These waste characteristics are based on the assumption that spent fuel is reprocessed and plutonium is recycled.

It is assumed that standard containers will be used for storage of each waste type. High level waste, cladding waste, and intermediate level waste require external shielding and the reference design calls for canisters identical in design, each having a waste volume of .18 cubic meters. A proposed canister design is shown in Fig. 2. Low level waste does not require external shielding and will probably be delivercd in 55-gal drums each having a waste volume of .21 cubic meters. 
'lable 1. Descriptions of nuclear waste types accepted at the reference design waste terminal storage facility

High level wastes ( $H L W$ ) are solidified composites of liquid waste arising from reprocessing of spent fuels

High level wastes contain:

1. $99.9 \%$ of nonvolatile fission products in spent fuel

2. $0.5 \%$ of uranium and plutonium in spent fuel

3. Virtually all the actinides other than $\mathrm{Pu}$ and $\mathrm{U}$ produced by transmutation of uranium and plutonium in the reactor

Cladding wastes (CW) are solid fragments of Zircaloy and stainless steel and other structural components of fuel assemblies that remain after the fuel cores have been dissolved.

Cladding wastes contain:

1. Noutron-indused radioastive produotc

2. $0.05 \%$ of actinides in spent fue 1

3. $0.05 \%$ of nonvolatile fission products

Intermediate-level transuranic wastes (ILW) are those solid or solidified materials that contain long-lived alpha emitters at concentrations greater than $10 \mathrm{nCi} / \mathrm{g}$, and have typical surface dose rates between 10 and $1000 \mathrm{millirems} / \mathrm{hr}$ after packaging

Low-level transuranic wastes (LLW) are those solid or solidified materials that contain plutonium or other long-lived alpha emitters in known or suspected concentrations greater than $10 \mathrm{nCi} / \mathrm{g}$, and have sufficiently low external radiation levels that they can be handled directly

Table 2. Characteristics of nuclear waste types accepted at the reference design waste terminal storage facility

\begin{tabular}{|c|c|c|c|c|}
\hline $\begin{array}{l}\text { Waste } \\
\text { type }\end{array}$ & $\begin{array}{l}\text { Approximate } \\
\text { density }\end{array}$ & $\begin{array}{l}\text { Approximate } \\
\text { composition }\end{array}$ & $\begin{array}{l}\text { Approximate } \\
\text { actinide } \\
\text { content }\end{array}$ & $\begin{array}{l}\text { Approximate } \\
\text { surface } \\
\text { dose rate }\end{array}$ \\
\hline HLW & $3.3 \mathrm{~g} / \mathrm{cc}$ & $\begin{array}{l}\mathrm{SiO}_{2} 25-40 \mathrm{wt} \% \\
\mathrm{~B}_{2} \mathrm{O}_{3} \quad 10-15 \mathrm{wt} \% \\
\text { Waste oxidés } 2 \dot{U}-35 \text { wt\% } \\
\mathrm{Zno} 5-10 \mathrm{wt} \% \\
\text { Alkali metal oxides } 5-10 \mathrm{wt} \%\end{array}$ & $70 \mathrm{~kg} / \mathrm{m}^{3}$ & $\begin{array}{l}10^{5}-10^{6} \mathrm{rem} / \mathrm{hr} \\
\text { at canister surface }\end{array}$ \\
\hline SW & $4.5 . g / c c$ & $\begin{array}{l}\text { Zircaloy } 88 \text { wt } \%^{a} \\
\text { Stainless steel } a^{y} \text { wt } \%^{\prime} \\
\text { Inconel } 2.5 \text { wt }{ }^{\prime}\end{array}$ & $6.65 \mathrm{~kg} / \mathrm{m}^{3}$ & $\begin{array}{l}10^{3} \text { rem } / \mathrm{hr} \\
\text { at canistèr surface }\end{array}$ \\
\hline ILW & $\begin{array}{l}2 \mathrm{~g} / \mathrm{cc} \\
\text { (compacted) }\end{array}$ & $\begin{array}{l}\text { Metals, ceramics, ash } \\
\text { fission products, } \\
\text { actinides }\end{array}$ & $10 \mathrm{~g} / \mathrm{m}^{3}$ & $\begin{array}{l}10-1000 \mathrm{mrem} / \mathrm{hr} \\
\text { at canister surface }\end{array}$ \\
\hline LLW & $\begin{array}{l}2 \mathrm{~g} / \mathrm{cc} \\
(\text { compacted) }\end{array}$ & Same as for ILW & $50-100 \mathrm{~g} / \mathrm{m}^{3}$ & $\begin{array}{l}<10 \mathrm{mrem} / \mathrm{hr} \\
\text { at canister surface }\end{array}$ \\
\hline
\end{tabular}

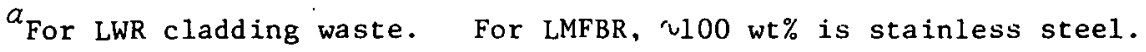


Table 3. Grams of heavy metals in spent fuel and reprocessed nuclear waste for one MT of PWR fue ${ }^{a}$

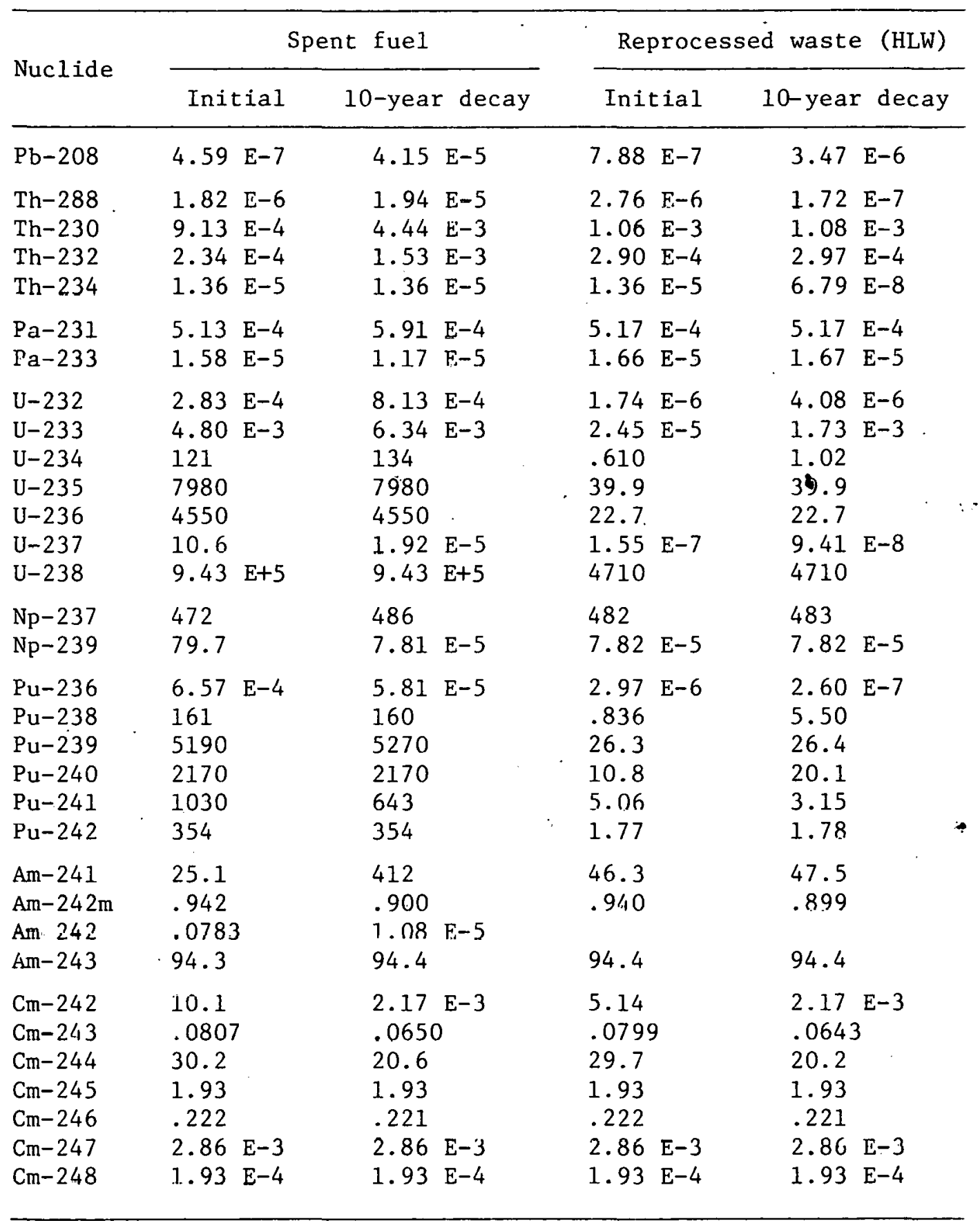

$a_{3.3 \%}$ enriched $\mathrm{U}-235 ; 33,000$ MWD burnup. 
Table 4. Estimated $(\alpha, n)$ and spontaneous fission neutron production rates in nuclear wastes (per $\mathrm{m}^{3}$ of waste)

\begin{tabular}{|c|c|c|c|c|}
\hline Waste type & $\begin{array}{c}\text { Neutron } \\
\text { source }\end{array}$ & $\begin{array}{c}\text { Initial } \\
\left(n / s-m^{3}\right)\end{array}$ & $\begin{array}{l}\text { One year } \\
\left(n / s-m^{3}\right)\end{array}$ & $\begin{array}{l}\text { Ten years } \\
\left(n / s-m^{3}\right)\end{array}$ \\
\hline HLW & $\begin{array}{l}\text { S. F. } \\
(\alpha, \mathrm{n}) \\
\text { Total }\end{array}$ & $\begin{array}{l}5.65 \times 10^{9} \\
7.13 \times 10^{8} \\
6.36 \times 10^{9}\end{array}$ & $\begin{array}{l}4.46 \times 10^{9} \\
2.12 \times 10^{8} \\
4.67 \times 10^{9}\end{array}$ & $\begin{array}{l}2.98 \times 10^{9} \\
5.82 \times 10^{7} \\
3.04 \times 10^{9}\end{array}$ \\
\hline $\begin{array}{c}\text { CW (com- } \\
\text { pacted) }\end{array}$ & $\begin{array}{l}\text { S.F. } \\
(\alpha, n) \\
\text { Tutal }\end{array}$ & $\begin{array}{l}2.96 \times 10^{6} \\
4.16 \times 10^{5} \\
3.38 \times 10^{6}\end{array}$ & $\begin{array}{l}2.52 \times 10^{6} \\
2.25 \times 10^{5} \\
2.75 \times 10^{6}\end{array}$ & $\begin{array}{l}1.60 \times 10^{6} \\
9.04 \times 10^{4} \\
1.69 \times 10^{6}\end{array}$ \\
\hline $\mathrm{ILW}^{a}$ & $\begin{array}{l}\text { s.f. } \\
(\alpha, n) \\
\text { Total }\end{array}$ & $\begin{array}{l}494 \times 10^{3} \\
7.02 \times 10^{4} \\
5.64 \times 10^{5}\end{array}$ & $\begin{array}{l}4.25 \times 10^{5} \\
3.81 \times 10^{11} \\
4.63 \times 10^{5}\end{array}$ & $\begin{array}{l}2.70 \times 10^{5} \\
1.52 \times 10^{4} \\
2.85 \times 10^{5}\end{array}$ \\
\hline LLW $^{\prime L}$ & $\begin{array}{l}\text { S. } \bar{F} . \\
(\alpha, n) \\
\text { Total }\end{array}$ & $\begin{array}{l}\sim 2.9 \times 10^{4} \\
\sim 6.4 \times 10^{4} \\
\sim 9.3 \times 10^{4}\end{array}$ & $\begin{array}{l}\sim 2.9 \times 10^{4} \\
\sim 6.7 \times 10^{4} \\
\sim 9.6 \times 10^{4}\end{array}$ & $\begin{array}{l}\sim 2.9 \times 10^{4} \\
\sim 8.5 \times 10^{4} \\
\sim 1.1 \times 10^{5}\end{array}$ \\
\hline
\end{tabular}

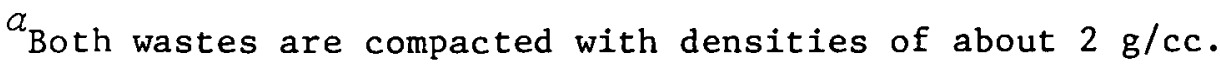

One projection ${ }^{12,13}$ of waste flows into the reference design repository is given in Table 5. In the year 2005, the projected annual number of HLW, CW, and ILW canisters is 35,320. The number of drums of LLW for Lhe same year is 16,000 . This converts to an average of about 1400 drums per week or about 200 drums per day. Thus, any material control and accountability system and its associated record keeping must be designed for high throughputs.

Wastes other than the four types described in Table 1 may be accepted at waste terminal storage facilities in the event that spent fuel is not reprocessed or plutonium is not recycled. These inr 1ute spent fucl clc ments and high level waste sontaining unseparatcd plutonium. These alternate waste types are described and the accountability requirements for a waste repository handling such waste types are briefly discussed in Appendix A. 


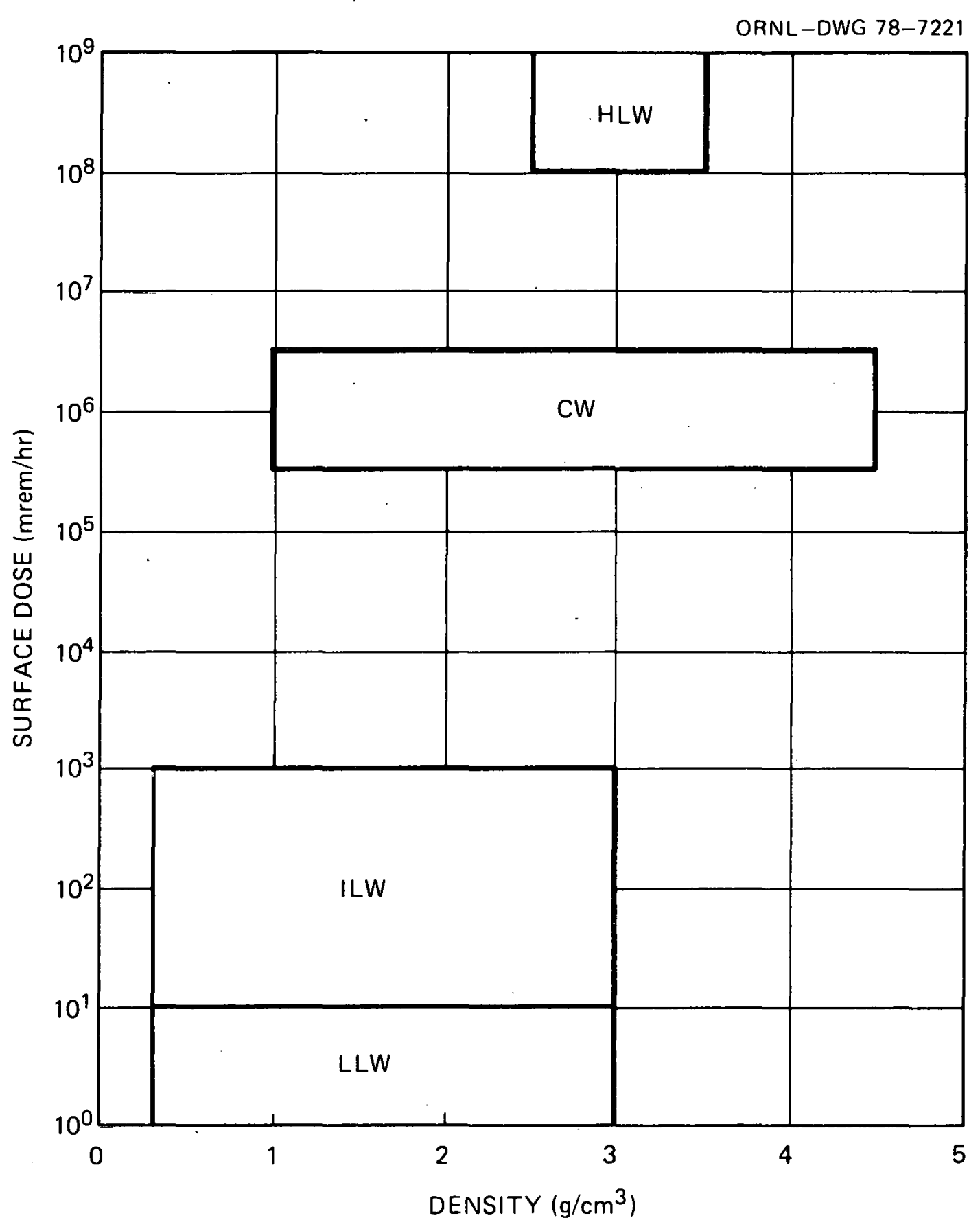

Fig. 1. Estimated ranges of density and surface dose rate for nuclear wastes. 
ORNL-DWG 78-7218

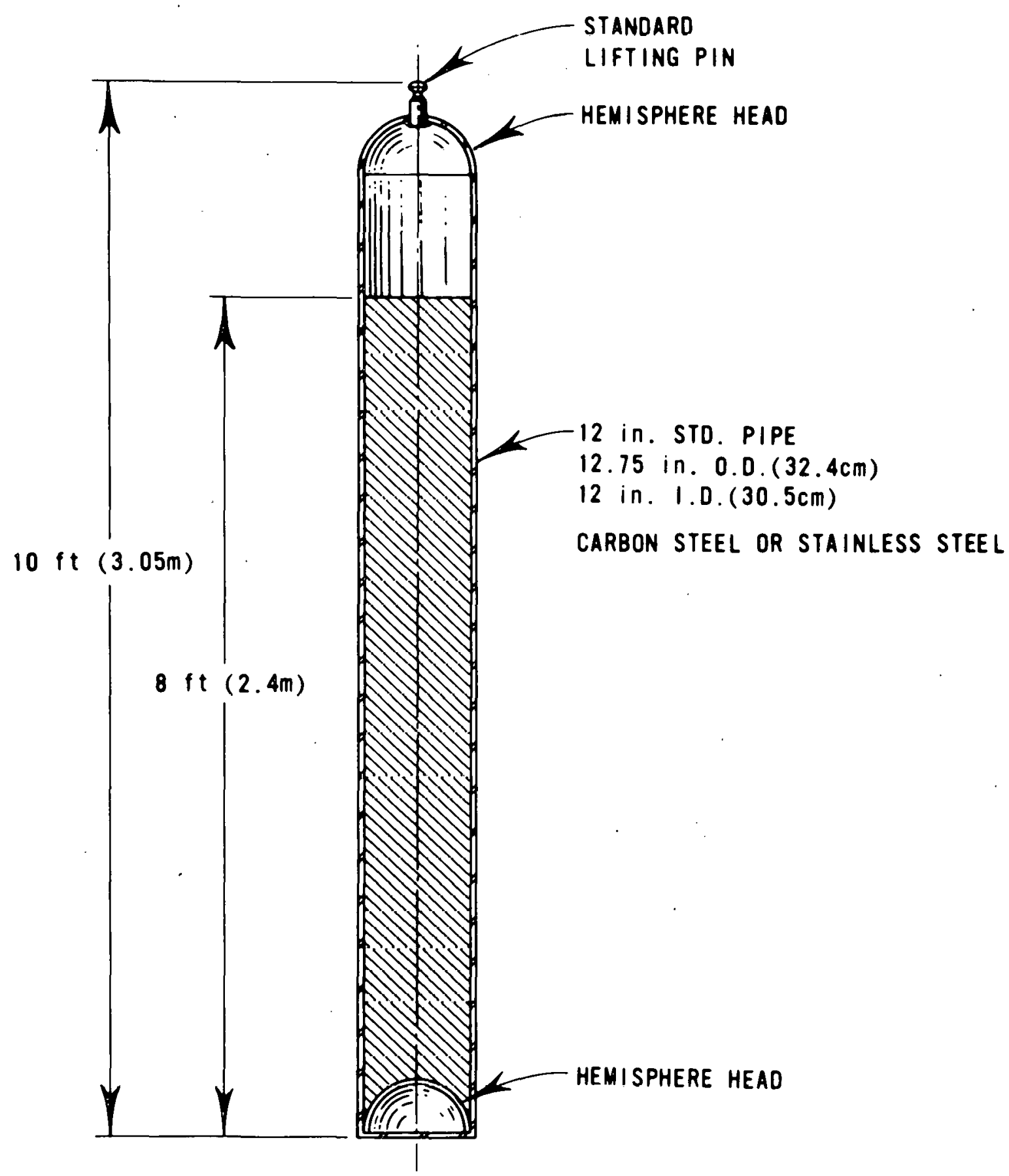

Fig. 2. Assumed standard canister for high-level, cladding, and intermediate-level wastes (generic repository description) (original figure: OWI-76-301). 
Table 5. Projection of number of waste units to be available for storage $a, b$

\begin{tabular}{|c|c|c|c|c|c|c|}
\hline \multirow{2}{*}{ Year } & \multicolumn{2}{|c|}{ High level } & \multicolumn{2}{|c|}{$\begin{array}{l}\text { Intermediate level } \\
\text { and cladding }\end{array}$} & \multicolumn{2}{|c|}{ Low level } \\
\hline & Annual & Accumulated & Annual & Accumulated & Annual & Accumulated \\
\hline 1983 & & & 1,930 & 1,930 & 480 & 480 \\
\hline 1984 & & & 4,360 & 6,290 & 1,440 & 1,920 \\
\hline 1985 & & & 8,080 & $14,370^{\circ}$ & 2,440 & 4,330 \\
\hline 1986 & & & 9,890 & 24,260 & $\therefore 13,900$ & 18,300 \\
\hline 1987 & & & 8,760 & 33,020 & 22,100 & 40,400 \\
\hline 1988 & 230 & 230 & 7,070 & 40,090 & 29,800 & 70,200 \\
\hline 1989 & 510 & 730 & 7,850 & 47,940 & 16,800 & 87,000 \\
\hline 1990 & 850 & 1,580 & 9,150 & 57,090 & 18,300 & 105,000 \\
\hline 1991 & 1,020 & 2,600 & 9,950 & 67,040 & 20,200 & 125,000 \\
\hline 1992 & 1,020 & 3,620 & 11,420 & 78,460 & 22,600 & 148,000 \\
\hline 1993 & 1,020 & 4,630 & 3,480 & 86,940 & 22,600 & 171,000 \\
\hline 1994 & 1,240 & 5,880 & 9,260 & 96,200 & 24,500 & 195,000 \\
\hline 1995 & 1,470 & 7,340 & 11,190 & 107,390 & 25,000 & 220,000 \\
\hline 1996 & 1,750 & 9,100 & 12,570 & 119,960 & 26,400 & 247,000 \\
\hline 1997 & 2,150 & 11,200 & 14,500 & 134,460 & 31,300 & 278,000 \\
\hline 1998 & 2,030 & 13,000 & 15,880 & 150,340 & 32,700 & 311,000 \\
\hline 1999 & 2,320 & 15,600 & 17,260 & 167,600 & 35,100 & 346,000 \\
\hline 2000 & 2,540 & 18,100 & 18,750 & 186,350 & 38,500 & 324,000 \\
\hline 2001 & 2,830 & 21,000 & 20,790 & 207,140 & 42,800 & 427,000 \\
\hline 2002 & 3,110 & 24,100 & 22,720 & 229,860 & 47,600 & 475,000 \\
\hline 2003 & 3,450 & 27,500 & 25,360 & 255,220 & 54,800 & 529,000 \\
\hline 2004 & 3,730 & 31,200 & 28,560 & 283,780 & 66,300 & 596,000 \\
\hline 2005 & 4,070 & 35,300 & 31,250 & 315,030 & 76,000 & 672,000 \\
\hline
\end{tabular}

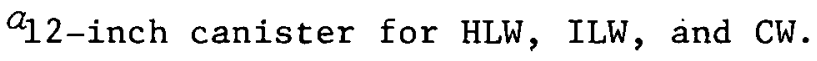

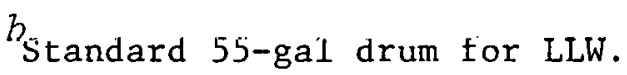

\section{LEVELS OF MATERIAL CONTROL}

Cuntrol and accountabll1ty of special nuclear material at waste terminal storage facilities can be performed at three levels. These are: identification and item control, tamper-indication, and quantitative material assay. At the item control and identification level, one would either insure that the proper number of containers had been received, and each container could be given a unique identification for control and 
record management. Tamper-indication procedures would be employed to determine whether material had been diverted during shipment. Material assay procedures including detailed record management would be required to account quantitatively for the special nuclear material in waste. Each higher level of accountability presupposes the existence of the lower ones.

The various identification procedures, tamper-indication procedures, and material accountability procedures discussed in this paper are given in Table 6.

Table 6. Methods for special nuclear material accountability at waste terminal storage facilities

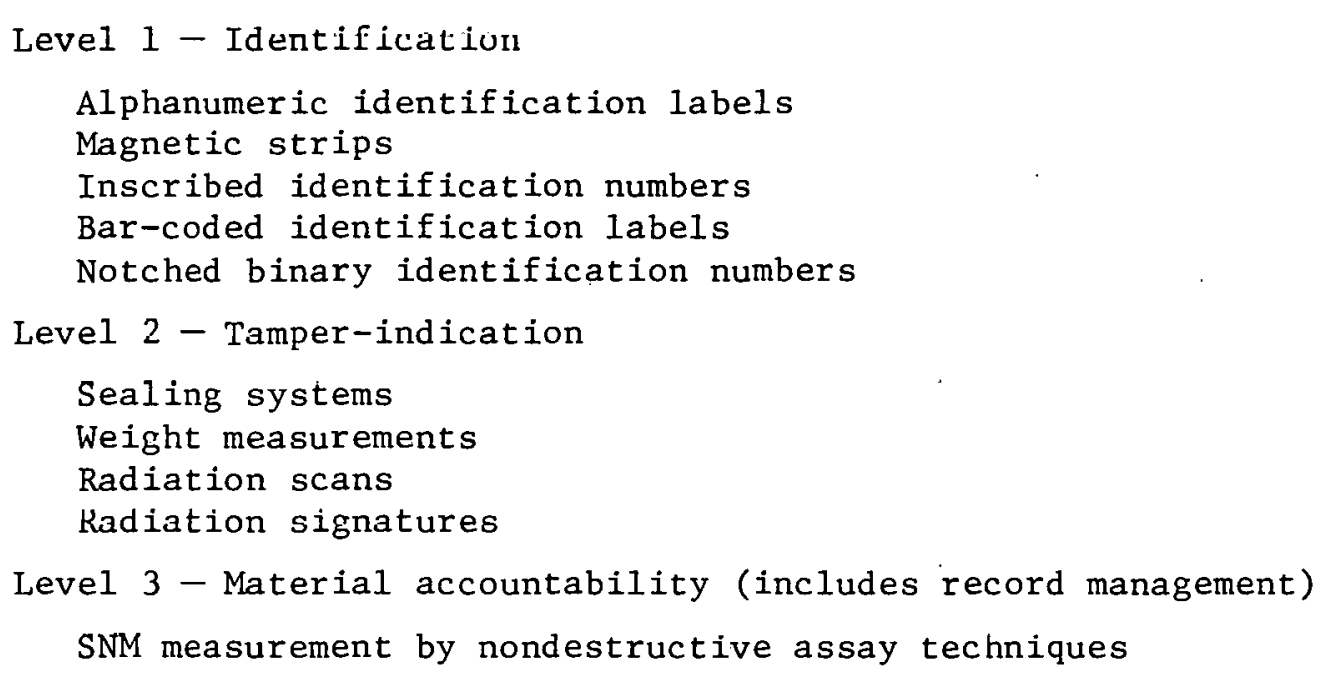

\section{EVALUATION OF MATERIAL CONTROL AND} ACCOUNTABILITY NEEDS

The waste materials to be handled at the terminal storage facility are generally unattractive targets for diversion. Radiation levels are often high, SNM content is dilute and the form of the waste makes recovery difficult. Nevertheless, adequate control of this material is essential because of its radioactivity and because it is necessary to assure that all waste materials shipped from production facilities have been received without alteration and are properly stored at the repository. 
Clearly the most satisfying solution is to account in detail for the constituents of each container, both prior to shipment and after receipt. Such quantitative assay would not only insure the integrity of the package but would also serve to close the SNM material balance loop by providing an independent and final determination on the amount of material discarded. Unfortunately, as described in our technical evaluation, the physical and radiological characteristics of all four waste types make such measurements, to the accuracy required to insure integrity of the shipment, extremely difficult and, in many cases, impossible. Hence some lower levels of material control must be implemented. The appropriate and reasonable level for each type of waste will be considered below.

High level waste is generated at the downstream end of a fuel reprocessing plant. It will be produced initially in liquid form and stored in large ( 2500,000 gal) tanks for a significant length of time. Prior to encapsulation it will be solidified and bound in a nonleachable matrix.

The properties of this material make it almost inconceivable that anyone would attempt its diversion in transit in order to gain access to its SNM content. First, the material incorporates the bulk of the radioactive fission products with their associated lethal radiation levels. Second, since a major effort will already have been expended to extract the plutonium while the material was in liquid form and since the material has subsequently been rendered even less accessible by solidification, the difficulty of extracting usable amounts of plutonium, even if one had access to the material, is enormous. Accordingly, we conclude that item accountability and identification (Level 1 material control measures) are sufficient for high level waste canisters.

Cladding wastes are similar in that they too have high radiation levels and the residual SNM is insoluble. Here again, material control measures are needed only to insure and demonstrate safe delivery of the material. We conclude Level 1 measures will suffice.

Since both high level and cladding wastes will be delivered in welded containers, and since they will almost certainly be checked for integrity on receipt, tamper indication control measures are, in fact, also being practiced. Because of the material characteristics described above, 
breach of containment on these materials might incur concern about possible en route loss and contamination but should not cause concern from an SNM diversion point of view.

Intermediate level waste does not have the valuable (from a safeguards point of view) attribute of surrounding itself with lethal radiation levels. In addition, while its average SNM content per cubic meter is low, its polymorphic composition admits the possibility of significant SNM in a single container and its relatively low radiation level is insufficlent to defer a dedicated diverter. We therefore conclude that the second level of material control. should be explicitly required for ILW, i.e., both item identification and explicit tamper indication checks. If, as we hypothesize in this paper, ILW is delivered in sealed welded containers, additional tamper indicators would be unnecessary. Leak tests, contamination wipes or visual inspection for possible intrusion would be sufficient to determine if the integrity of the container had been breached.

Low level waste presents by far the greatest problem from a material accountability and control point of view. It originates from a variety of sources both in fuel reprocessing and refabrication and in many cases may result from personnel accessible operations, e.g., equipment maintenance, waste sorting and processing, and canister filling. For these reasons the possibility of inclusion of off spec amounts of special nuclear material, either by error or by design, is greater than for the other waste types. It is our opinion, however, that the place to affect the required levels of material control to insure that such errors or diversions do not occur is at the point where the waste materials are encapsulated. The material balance for a given facility, with respect to its off site waste shipments, should be closed when the material is sealed in the cans, and a verification by the waste repository as to explicit contents of individual drums should not be necessary.

The reasons for this are threefold. First, the shipper has access to the material prior to encapsulation and can therefore implement much more accurate material measurement techniques either by sampling or by assay of individual components prior to canning. 
Second, if assay of encapsulated wastes is deemed necessary, the shipper will have access to the data on the material composition of each drum and will be able to construct and maintain calibration standards peculiar to his types of waste. In addition, since the variety of wastes from a given shipper will certainly be less than the total spectrum received by a repository, the shipper can design and implement NDA techniques suited to and optimized for his particular types of waste.

Third, since one purpose of material control ithe timely detection of loss or diversion of special nuclear material, the discovery of inconsistencies in container contents on receipt at the repository will probably be too late to be effective.

In summary, responsibility for detailed material accountability in LLW should be the responsibility of the shipper. Processes and regulations should be designed accordingly. The waste repository should verify that it received, intact, what was shipped and hence item accountability and tamper indication procedures should be sufficient.

\section{TECHNICAL OPTIONS FOR ITEM CONTROL}

The waste container is the basic unit for the item accountability level of material management at a repository. We have already expressed the opinion that item accountability be applied to all waste types, that each container should be uniquely identified, and that simple enumeration of containers is insufficient. The hostile nature of nuclear waste, the loss of public confidence in the event of container loss or misplacement, and the fact that all 55-gal drums and 12-in. pipes look very much alike make the additional chores involved in the marking of waste canisters and the associated record keeping seem small in comparison to the added assurance gained by implementing such a system.

There are certain characteristics that identifications selected for waste containers should have. The identifications should not be easily damaged. The identifications should be difficult to alter or duplicate. Due to the high volumes which must be processed and the radiation levels associated with three of the four types of waste, the identifications would have to be adaptable to autumatic reading. 
There are many identification procidures that can be used for nuclear waste containers. Five are considered in this paper and an infinite number of variations on these five procedures are possible. The five identifications discussed are: alphanumeric identification labels, magnetic strips, inscribed identification numbers, bar-coded identification, and notched binary 1dentification numbers.

Labels written in alphanumeric characters are possibly the simplest form of identification. There are several disadvantages however. The labels are sensitive to damage, easily duplicated, and difficult to read automatically.

Magnelic serips containing the identification information are more difficult to alter or duplirate and san bo rcad automalically. However, they are susceptible to damage especially by strong magnetic fields.

Both labels and magnetic strips suffer from the fact that the high temperatures associated with HLW might tend to decompose or obscure the information.

Identification numbers inscribed on the metal waste containers have the advantage of insensitivity to accidental damage (e.g., intense heat or mechanical abrasion) and are difficult to alter. However, inscribed numbers are not easily adaptable to automatic reading.

Identifications using bar codes such as the Universal. Product Code (UPC) have several advantages. The bar-coded information can be painted or inscribed on the container surface or put on labels which are then attached to the container. The information can be automatically read. The coding system can be unique making alteration or duplicatinn very difficult. A large amount of information can be contained in each bar-coded label. 'l'he coded information could include: container identification number, shipper identification number, SNM content, total weight, surface radiation level, etc. In addition a coded check number to determine whether the information has been correctly read or altered can be included. A disadvantage of bar code labels is that they may be damaged during shipment as discussed above. However, the codes can be inscribed into the container surface to reduce the possibility of identification being obliterated. 
An alternate coded identification technique is notched binary. In notched binary identifications, a series of, notches are placed at a specific axial location along the circumference of the waste container. Each notch or absence of a notch would répresent the binary digit 1 or 0 . If there are 17 notch locations, any decimal number up to 131071 can be uniquely determined. To read the identification number, a mechanism would move over the notch locations recording the presence or absence of notches.

These last two identification procedures have several advantages. The identifications would be insensitive to damage, difficult to alter or duplicate, and adaptable to automatic reading. However, they require that shippers have either prefabricated marked waste containers or machines for cutting the identifications. Also, shippers and the waste terminal storage facility would have to have mechanical devices to read the inscribed identifications.

Table 7 summarizes the advantages and disadvantages of the various identification systems.

Our preference, in light of the considerations listed above, is that permanent identification (notched binary alphameric or UPC) be inscribed in the container surface. Further study will be required to determine the optimum system for each waste type.

\section{TÉCHNICAL OPTIONS FOR TAMPER INDICATION}

We have recommended that level 2, e.g., tamper indication procedures, be applied to ILW and LLW waste containers because these containers lack the protection against diversion afforded by high radiation levels and may, on occasion, contain significant amounts of nuclear material.

Sealing systems have been successfully used in the transportation industry for many years. Sealing systems employ mechanical seals to indicate tampering. If entry or tampering occurs during shipment, the seals are damaged. The seals would be placed on the outside of the cargo access of the waste carrier and on the shipment containers of the waste canisters. A disadvantage of sealing systems is that occasionally seals are accidentally damaged and back-up procedures to indicate tampering 
Table 7. Advantages and disadvantages of identification procedures

\begin{tabular}{|c|c|c|}
\hline Identification procedure & Advantages & Disadvantages \\
\hline $\begin{array}{l}\text { Alphanumeric identifi- } \\
\text { cation labels }\end{array}$ & $\begin{array}{l}\text { Conventional procedure } \\
\text { easy to implement }\end{array}$ & $\begin{array}{l}\text { Susceptible to duplica- } \\
\text { tion or alteration } \\
\text { Susceptible to acciden- } \\
\text { tal damage } \\
\text { Difficult to read auto- } \\
\text { matically }\end{array}$ \\
\hline Magnetic strips & $\begin{array}{l}\text { Difficult to alter or } \\
\text { duplicate } \\
\text { Adaptable to auto- } \\
\text { matic reading }\end{array}$ & $\begin{array}{l}\text { Susceptible to acciden- } \\
\text { tal damage }\end{array}$ \\
\hline $\begin{array}{l}\text { Inscribed identifi- } \\
\text { cation numbers }\end{array}$ & $\begin{array}{l}\text { Conventional procedure } \\
\text { easy to implement } \\
\text { Resistant to acciden- } \\
\text { tal damage }\end{array}$ & $\begin{array}{l}\text { Difficult to read } \\
\text { automatically. Most } \\
\text { applicable to LLW cans. }\end{array}$ \\
\hline $\begin{array}{l}\text { Bar-coded identifica- } \\
\text { tion labels }\end{array}$ & $\begin{array}{l}\text { Adaptable to automatic } \\
\text { reading } \\
\text { Difficult to alter or } \\
\text { duplicate }\end{array}$ & $\begin{array}{l}\text { Susceptible to acciden- } \\
\text { tal damage unless } \\
\text { inscribed }\end{array}$ \\
\hline $\begin{array}{l}\text { Notched binary identifi- } \\
\text { cation numbers }\end{array}$ & $\begin{array}{l}\text { Adaptable to auto- } \\
\text { matic reading } \\
\text { Resistant to acciden- } \\
\text { tal damage } \\
\text { Difficult to alter }\end{array}$ & $\begin{array}{l}\text { Not commonly used pro- } \\
\text { cedure } \\
\text { Development work needed } \\
\text { (mechanical reader } \\
\text { devices and machines } \\
\text { for making notched } \\
\text { idcntifications) }\end{array}$ \\
\hline
\end{tabular}

are required. For nuclear waste containers, back-up tamper-indicating procedures may be weight measurements and radiation scans.

Weight measurements and radiation scans can be used to indicate material loss and to supplement sealing systems. In weight measurement procedures, the weight of the container and contents would be accurately measured and compared with shipper values. In radiation scan procedures, the gross gamma and/or neutron radiation levels would be measured at a specific distance from the container and compared to shipper values. Elaborate instrumentation would not be required for weight or radiation scan measurements.

Radiation signature procedures could be employed to give nearly positive indication of whether tampering had occurred. Radiation 
signatures are measurements of certain energy gammas or gamma energy spectra and/or neutron energy spectra. The radiation signatures would be taken by the shipper before shipment and by the repository after shipment. If the signatures do not match, tampering would be assumed. There are many disadvantages of this procedure. Elaborate instrumentation is required and all shippers and the repository would have to have identical instrumentation for valid signature comparison. In addition, different instrumentation may be required for each waste type as the emitted radiation differs significantly for different waste types. Also, computer data analysis systems and possibly several instruments for each waste type would be required. Additional personnel would also be required at the waste terminal storage facility to operate and service the radiation signature instrumentation.

Table 8 lists the advantages and disadvantages of the various tamperindicating systems. Our preference is for a well designed sealing system with weight and radiation level measurements for backup.

Table 8. Advantages and disadvantages of tamper-indicating procedures

\begin{tabular}{|c|c|c|}
\hline $\begin{array}{c}\text { Tamper-indicating } \\
\text { procedure }\end{array}$ & Advantages & Disadvantages \\
\hline Sealing systems & $\begin{array}{l}\text { Well developed-commonly } \\
\text { used in transportation } \\
\text { industry }\end{array}$ & $\begin{array}{l}\text { Seals susceptible to } \\
\text { accidental damage- } \\
\text { need backup pro- } \\
\text { ledule }\end{array}$ \\
\hline Weight measurements & Easy to implement & $\begin{array}{l}\text { Not a positive tamper- } \\
\text { indicating procedure }\end{array}$ \\
\hline Radiation scans & $\begin{array}{l}\text { Easy to implement } \\
\text { Difficult to duplicate }\end{array}$ & $\begin{array}{l}\text { Not a positive tamper- } \\
\text { procedure }\end{array}$ \\
\hline Radiation signatures & $\begin{array}{l}\text { Nearly positive tamper- } \\
\text { indicator }\end{array}$ & $\begin{array}{l}\text { Idendical instrumenta- } \\
\text { tion required by all } \\
\text { shippers and the } \\
\text { repository } \\
\text { Repository design and } \\
\text { operation complicated }\end{array}$ \\
\hline
\end{tabular}




\section{TECHNICAL OPTIONS FOR SNM ASSAY}

We have, in the preceding discussion, rather summarily dismissed quantitative material assay from an important role in the material accountability procedures at a waste repository. This dismissal rests on the unfortunate reality that the physical and radiological characteristics of the various waste materials preclude measurements of sufficient accuracy to provide information of any great value.

In our technical evaluation ${ }^{2}$ we analyzed the various NDA technologico and their applicability to the several waste types and arrived at the following senclueione.

1. It is not technologically reasonable to attempt to assay high level and cladding waste. The radiation levels and low SNM contents exclude practical application of both passive and active techniques.

2. The properties of low level and intermediate level waste also make assay very difficult. The measurement accuracy for NDA methods is generally low for high density material, for low SNM concentrations, for high background radiation levels, for heterogeneous material mixtures, and for large container volumes. Both LLW and ILW have these properties in varying degrees. Also for independent NDA analysis at the waste storage facility, the chemical composition of the waste, the homogeneity of the SNM distribution, and the isotopic composition of the SNM must be known. This further complicates the assay of these wastes at the repository.

3. If SNM measurement is implemented at the waste storage facility, effects on the facility design could be significant. Separate shielded assay rooms in the facility would be necessary. Automated waste container flow systems coupled with container identification instrumentation and computer data analysis systems would be required. Different NDA instrumentation would be necessary for each waste type since different types have differing SNM contents, container sizes, radiation levels, etc. Several standard waste samples of each waste type would be 
necessary for NDA analysis. Assay times are long (of the order of $20 \mathrm{~min}$ ) and several flow lines would be necessary to prevent pile-ups in the surface storage areas. In addition, an increase in personnel at the waste terminal storage facility would be required to operate and service the assay equipment. If, despite the above complications, quantitative assay is attempted, accuracies in the 15 to $30 \%$ range are probably all that can be achieved.

It is possible that regulatory decisions may require nondestructive assay techniques at a repository despite the limitations described above. In this event, the following technical considerations should be considered in the selection and implementation of specific assay instrumentation.

1. Calorimetric techniques are not applicable to the types of material and containers expected at a waste repository.

2. Assay of High Level and Cladding Waste canisters by nondestructive techniques to determine residual fissile material content is almost impossible using available technology. The probability of success for developing such techniques for routine application is very small.

3. Assay of Intermediate Level Waste canisters for fissile content using passive gamma or neutron techniques is not feasible because of the high fission product gamma activity and neutron activity from the higher actinides.

4. Assay of Low Level Waste by passive gamma methods is possible but severely complicated by the high density and variability of the waste material and by the need to calibrate measured results against representative standards. For well characterized low level wastes, passive gamma techniques can be employed, but the possibility of unknown matrix inhomogeneities reduces confidence in such measurements.

5. Assay of Low Level Waste by passive neutron methods is possible, but complications due to the presence of $(\alpha, n)$ neutrons and uncertainties in plutonium isotopics relegates these methods to the "consistency check" level. 
6. Active interrogation methods, using either gammas or neutrons, are the most promising techniques for quantitative determination of the fissile content of intermediate and low level waste containers. Highest accuracies (5-20\%) may be achieved on LLW in 55-gal drums using particle accelerators to generate the interrogating radiation but these bring with them the attendant problems of high cost and potential operating and maintenance problems. Isotopic $\left[{ }^{252} \mathrm{Cf}\right.$ or $\left.(\gamma, n)\right]$ sources can be successfully employed to assay these types of waste, probably to accuracies of $\sim 10$ to $\sim 30 \%$. Assay times to achieve these accuracies will be of the order of $10 \mathrm{~min} / \mathrm{drum}$.

Several different doviooc, tailorcd to sperific waste lypes within each category, will probably be required to cover the spectrum of materials and activities in the low and intermediate waste categories. Major development work will be required to implement such a system.

7. Attribute measurements, go, no-go measurements, and radiation signature measurements are simpler to make and are well within the range of existing technology. While specific equipment would have to be designed for these applications, we see no severe technical problems. These measurements could be made by passive or by a combination of active-passive techniques using isotopic sources.

\section{CONCLUSIONS AND RECOMMENDATIONS}

Three levels of material control and accountability procedures for special nuclear material at waste terminal storage facilities have been identified as: identification and item accountability, tamper-indication, and material assay. We have argued that each waste container must have a unique identification for record management and control. Tamperindicating procedures should be practiced on ILW and LLW canisters to determine if the containers have been breached during shipment. Quantitative assay should not be attempted or required. 
Several identification procedures, tamper-indication procedures, and material assay procedures have been considered.

of the five identification procedures considered, alphanumeric identification labels and magnetic strips are of questionable utility, being too susceptible to accidental damage such as fire, abrasion, or strong magnetic fields. Notched binary identification numbers and inscribed bar-coded identification have the advantage of being adaptable to automatic reading although they are more complex identifications than are inscribed numbers. The waste terminal storage facility and the waste shippers will have to decide if the identification. symbols should be automatically read. An identification procedure to allow automatic reading should be considered especially when evaluating HLW, CW, and ILW waste container identification requirements.

Radiation signature verification is an expensive tamper-indicating procedure requiring elaborate instrumentation and complicating the waste repository design and operation. For these reasons it is considered an inappropriate tamper-indicating procedure. Sealing systems are welldeveloped, are commonly used, and are easy to implement. However, as seals may be accidentally damaged, back-up tamper-indicating procedures are required. Weight measurements and gross radiation scans could satisfy this need. Shippers would be required to weigh and scan each waste container before shipment.

Special nuclear material assay would significantly complicate waste terminal storage facility design and operation. In addition, SNM measurement accuracy would be too low to be useful for absolute verification of shipper measurements. It is not recommended as a material control measure at a waste repository.

In view of the above we recommend the following procedures be followed for material control at a waste repository.

1. High Level Waste. Item control measures with unique container identification. Identification symbols should be inscribed on container surface and should probably be machine readable.

2. Cladding Waste. Same as for High Level Waste.

3. Intermediate Level Waste. In addition to item control measures described above; caplicit tamper indication procedurcs should 
be implemented. If container design does not provide sufficient assurance of maintenance of integrity, then a system of tamperindicating seals with weight and radiation scan backup should be employed.

4. Low Level Waste. Item control measures including unique inscribed identification. Tamper-indicating seals with weight and radiation scan measurements for backup. 


\section{REFERENCES}

1. E. D. Blakeman, E. J. Allen and J. D. Jenkins, An Evaluation of NDA Techniques and Instruments for Assay of Nuclear Waste at a Waste Terminal Storage Facility, ORNL/TM-6163 (to be published).

2. Code of Federal Regulations CFR-10, Revised Jan. 1, 1976, Part 70, 71 and 73 .

3. Serial Numbering of Fuel Assemblies for Light-Water-Cooled Nuclear Power Reactors, Regulatory Guide 5.1 (Dec. 20, 1972).

4. Selection and Use of Pressure-Sensitive Seals on Containers for onsite Storage of Special Nuclear Material, Regulatory Guide 5.10 (July 1973).

5. Security Seals for the Protection and Control of Special Nuclear Material, Regulatory Guide 5.15 (January 1974).

6. Evaluation of Shipper-Receiver Differences in the Transfer of Special Nuclear Material, Regulatory Guide 5.28 (June 1974).

7. Nondestructive Assay of Special Nuclear Material Contained in Scrap and Waste, Regulatory Guide 5.11 (October 1973).

8. Control and Accountability of Plutonium in Waste Material, Regulatory Guide 5.47 (February 1975).

9. Qualification, Calibration, and Error Estimation Methods for Nondestructive Assay, Regulatory Guide 5.53 (August 1975).

10. Shipping and Receiving Control of Special Nuclear Material, Regulatory Guide 5.57 (June 1976).

11. Waste Isolation Facility Description, Parsons Brinckerhoff Quade and Douglas, Inc., New York, Y/OWI/SUB-76/16506 (September 1976).

12. J. O. Blomeke and C. W. Kee, "Projections of Wastes to be Generated," International Symposium of Wastes from the LWR Fuel Cycle, Denver, Colorado, Ju1y 11-16, 1976.

13. C. W. Kee, A. G. Croff and J. O. Blomeke, Updated Frojectiono of Radioactive Wastes to be Generated by the U.S. Nuclear Power Industry, ORNL/TM-5427 (May 1976). 
THIS PAGE

WAS INTENTIONALLY

LEFT BLANK 
Appendix A

SNM ACCOUNTABILITY FOR ALTERNATE WASTE TYPES

The waste types discussed in the main body of this paper were based on certain reprocessing and fuel recycle assumptions. It was assumed that the fuel was reprocessed and that the plutonium was recycled. Other waste types would result if there was no reprocessing or if the plutonium was not recycled after reprocessing. The alternate waste types considered in this Appendix are described in Table Al.

Table Al. Alternate waste types for waste terminal storage facilities

\begin{tabular}{lcc}
\hline Waste type & Fuel cycle assumptions & Waste description \\
\hline Fuel assemblies & $\begin{array}{c}\text { No reprocessing, no fuel } \\
\text { recycle }\end{array}$ & Spent fuel assemblies \\
Plutonium in high & $\begin{array}{c}\text { Reprocessing, no } \\
\text { plutonium recycle }\end{array}$ & $\begin{array}{l}\text { Same waste types as in } \\
\text { Table 2 but HLW has } \\
\text { level waste }\end{array}$ \\
& $\begin{array}{l}\text { virtually all the Pu } \\
\text { in spent fuel }\end{array}$
\end{tabular}

As the SNM content has increased in the waste for these alternate fuel cycle assumptions, the attractiveness of the waste for theft has correspondingly increased. Safeguards measures related to the accountability of SNM at waste terminal storage facilities would have to be more stringent.

If the waste form is fuel assemblies, item accountability would be a reasonable accountability procedure to practice at waste terminal storage facilities. The fuel assemblies are closed containers which remain unopened before and after irradiation and would not be opened at the waste repository. Item accounting is the currently accepted practice at power reactors. Each fuel assembly is identified by a unique inscribed number. Measurements of SNM in the fuel assemblies are not made at power reactors. Similar accountability procedures' could be practiced at waste terminal 
storage facilities. In addition, as the irradiation history of each spent fuel assembly is well known, the SNM content in each assembly could be estimated.

If the plutonium is not recovered and remains in the high level waste, item accountability still remains the reasonable accountability procedure. The high level waste, even with the higher plutonium concentration, is so radioactive that the attractiveness for theft is low. Also, SNM measurement by NDA techniques would be complicated by the high background radiation level of fission products in the high level waste. 


\author{
ORNL/TM-6162 \\ Dist. Category UC-70
}

\title{
Internal Distribution
}

1-5. E. J. Allen

6. Seymour Baron

7-11. E. D. Blakeman

12. R. Blumberg

13. A. L. Boch

14. H. C. Claiborne

15. J. C. Cleveland

16. W. B. Cottrell

17. P. D. Fairchild

18. M. H. Fontana

19. A. J. Frankel

20. John F. Harvey

21. W. R. Hamel

22. H. W. Hoffman

23. R. M. Holmes

24. R. D. Hurt

25-29. J. D. Jenkins

30. G. H. Jenks

31. H. T. Kerr

32. R. K. Kibbe

33. M. Levenson

34. R. E. MacPherson

35. W. E. Manrod

36. S. C. Matthews

37. L. L. McCauley
38. W. C. McClain

39. S. R. McNeany

40. J. F. Mincey

41. J. M. Morrison

42. W. H. Pechin

43. R. T. Primm

44. A. S. Quist

45. H. N. Rosenberg

46. J. E. Rushton

47. M. R. Sheldon

48. I. Spiewak

49. E. G. St. Clair

50. W. E. Thomas

51. H. E. Tramme11

52. D. B. Trauger

53. J. E. VanCleve

54. G. D. Whitman

55. C. D. Zerby

56-57. Central Research Library

58. Document Reference Section

59-60. Laboratory Records Department

61. Laboratory Records, ORNL (RC)

62-86. Office of Waste Isolation (OWI) Records

87. ORNL Patent Office

\section{$\underline{\text { External Distribution }}$}

88. Director, Research and Technical Support Division

89. Director, Reactor Division

90-94. J. J. Schreiber, Director, Waste Management Division, U.S. Department of Energy, Washington, DC 20545

95. D. Davis, Department of Energy, Albuquerque Operations Office, Post office Box 5400, Albuquerque, NM 87115

96. T. B. Hindman, Department of Energy, Savannah River Operations Office, P.O. Box A, Aiken, SC 29810

97. C. D. Jackson, Director, Department of Energy, San Francisco Operations Office, 1333 Broadway, Wells Fargo Building, Oakland, CA 94612

98. K. N. Joy, Department of Energy, Nevada Operations Office, P.0. Box 14100, Las Vegas, NV 89114

99. D. J. Squires, Department of Energy, Richland Operations Office, P.0. Box 550, Richland, WA 99352

100. D. D. Wodrich, Rockwell International, Atomics Internatjonal Division, Rockwell Hanford. Operations, P.0. Box 800, Richland, WA 99352 
101. I. W'. Marine, E. I. duPont de Nemours and Company, Atomic Energy Division, Savannah River Laboratory, Aiken, SC 29801

102. W. D. Weart, Sandia Laboratories, P.O. Box 5800, Albuquerque, NM 87115

103-369. For distribution as shown in TIC-4500 under UC-70, General Reactor Technology. 